SJ Quinney College of Law, University of Utah Utah Law Digital Commons

Utah Law Faculty Scholarship

Utah Law Scholarship

9-2018

\title{
Gamble v. U.S.: Brief of Amici Curiae Law Professors in Support of Petitioner
}

Stuart Banner

UCLA School of Law

Paul Cassell

S.J. Quinney College of Law, University of Utah, paul.cassell@law.utah.edu

Follow this and additional works at: https://dc.law.utah.edu/scholarship

Part of the Constitutional Law Commons, and the Criminal Law Commons

\section{Recommended Citation}

Banner, Stuart and Cassell, Paul, "Gamble v. U.S.: Brief of Amici Curiae Law Professors in Support of Petitioner" (2018). Utah Law Faculty Scholarship. 122.

https://dc.law.utah.edu/scholarship/122

This Brief is brought to you for free and open access by the Utah Law Scholarship at Utah Law Digital Commons. It has been accepted for inclusion in Utah Law Faculty Scholarship by an authorized administrator of Utah Law Digital Commons. For more information, please contact

valeri.craigle@law.utah.edu. 


\section{$\mathfrak{I} \mathfrak{n}$ the \\ Supreme Court of the afmited States}

Terance Martez Gamble,

Petitioner,

V.

UNITED STATES,

Respondent.

\section{On Writ of Certiorari to the United States Court of Appeals for the Eleventh Circuit}

\section{BRIEF OF AMICI CURIAE LAW PROFESSORS IN SUPPORT OF PETITIONER}

$\begin{array}{ll}\text { PAUL G. CASSELL } & \text { STUART BANNER } \\ \text { S.J. Quinney College of Law } & \text { Counsel of Record } \\ \text { University of Utah } & \text { UCLA School of Law } \\ \text { 338 S. University St. } & \text { Supreme Court Clinic } \\ \text { Salt Lake City, UT 84112 } & \text { 405 Hilgard Ave. } \\ & \text { Los Angeles, CA 90095 } \\ & \text { (310) 206-8506 } \\ & \text { banner@law.ucla.edu }\end{array}$


TABLE OF CONTENTS

TABLE OF AUTHORITIES ...................................ii

INTEREST OF AMICI CURIAE ................................ 1

SUMMARY OF ARGUMENT ................................. 1

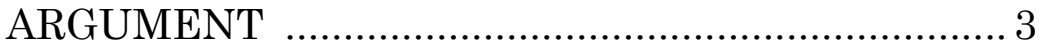

Dual sovereignty is an accident of history; it was not part of the constitutional design.

A. In Bartkus v. Illinois, the Court misunderstood the English and early American sources relevant to the origin of dual sovereignty.

B. Dual sovereignty was invented by this Court shortly before the Civil War, largely as a way of preventing free states from blocking the recapture of fugitive slaves.

C. In United States v. Lanza, the Court was concerned less with the original meaning of the Double Jeopardy Clause than with rampant disregard of Prohibition.

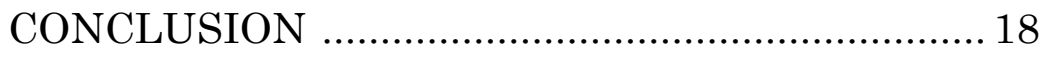




\section{TABLE OF AUTHORITIES}

\section{CASES}

Bartkus v. Illinois, 359 U.S. 121 (1959) .... 2, 3, 4, 5, 6 Beak v. Thyrwhit, 87 Eng. Rep. 124 (K.B. 1688) 3

Beak v. Tyrrell, 89 Eng. Rep. 411 (K.B.

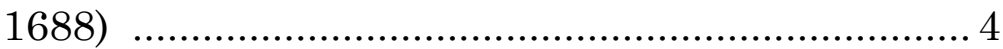

Beake v. Tirrell, 90 Eng. Rep. 379 (K.B. 1688) 4

Burroughs v. Jamineau, 25 Eng. Rep. 235

(Ch. 1727) 4

Burrows v. Jemino, 93 Eng. Rep. 815 (K.B. 1727) 4

Crawford v. Washington, 541 U.S. 36 (2004) .......... 17

Cross v. North Carolina, 132 U.S. 131 (1889) ......... 13

Crossley v. California, 168 U.S. 640 (1898) ............. 14

Ex parte Siebold, 100 U.S. 371 (1879) ..................... 13

Fox v. Ohio, 46 U.S. 410 (1847) ..................... 7, 9, 10 Gilbert v. Minnesota, 254 U.S. 325 (1920) .............. 14 Houston v. Moore, 18 U.S. 1 (1820) ............. 4, 5, 6, 13 McKelvey v. United States, 260 U.S. 353 14

Moore v. Illinois, 55 U.S. 13 (1852) ... 7, 10, 11, 12, 13

Pettibone v. United States, 148 U.S. 197 (1893) ......................................................... 13

Prigg v. Pennsylvania, 41 U.S. 539 (1842) ............... 8

R. v. Hutchinson (K.B. 1678) ................................... 3

R. v. Roche, 168 Eng. Rep. 169 (Cr. Cas. 1775) 3

Southern Ry. Co. v. R.R. Comm'n, 236 U.S. 439 (1915) 14

United States v. Furlong, 18 U.S. 184 (1820) 
United States v. Jones, 132 S. Ct. 945 (2012) ......... 17

United States $v . \quad$ Lanza, 260 U.S. 377

(1922) $2,13,14,15,16,17$

United States v. Marigold, 50 U.S. 560

(1850) 7,10

STATUTES

Fugitive Slave Act of 1793, 1 Stat. 302 8

Fugitive Slave Act of 1850, 9 Stat. 462

OTHER AUTHORITIES

Henry Bathurst, The Theory of Evidence

(1761) ............................................................... 4

Francis Buller, An Introduction to the Law

Relative to Trials at Nisi Prius (1768) ...................... 4

Joseph Chitty, A Practical Treatise on the

Criminal Law (1816) ............................................... 4

Timothy Cunningham, The Merchant's

Lawyer (1768) ........................................................ 4

Timothy S. Huebner, Liberty \& Union: The

Civil War Era and American Constitutionalism (2016) ................................................... 8

James Kent, Commentaries on American

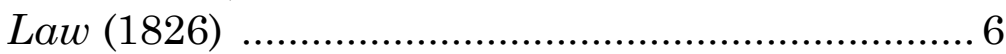

Michael A. Lerner, Dry Manhattan:

Prohibition in New York City (2007) .................... 15

Leonard MacNally, The Rules of Evidence on

Pleas of the Crown (1802) ......................................... 4

Edward D. Mansfield, The Political

Grammar of the United States (1835) ..................... 6

National Park Service, Dr. Richard Eells

House ................................................................. 11

William Rawle, $A$ View of the Constitution of

the United States of America (1825) 
Thomas Sergeant, Constitutional Law (2d ed. 1830) ......................................................... 6

Thomas Starkie, A Treatise on Criminal Pleading (1814) ...................................................... 4 John Strange, A Collection of Select Cases Relating to Evidence (1754) ...................................... 4 Francis Wharton, A Treatise on the Criminal Law of the United States (1846) ............................... 6 Francis Wharton, A Treatise on the Law of Homicide in the United States (1855) ....................... 6 


\section{INTEREST OF AMICI CURIAE}

Amici curiae are law professors who have studied the history of the dual sovereignty doctrine. The purpose of this brief is to provide the Court with additional historical information that will be useful in reconsidering dual sovereignty. ${ }^{1}$

Stuart Banner is the Norman Abrams Distinguished Professor of Law at UCLA.

Paul G. Cassell is the Ronald N. Boyce Presidential Professor of Criminal Law and the University Distinguished Professor of Law at the University of Utah.

Anthony Colangelo is the Gerald J. Ford Research Fellow and a Professor of Law at SMU.

Evan Lee is Emeritus Professor of Law at UC Hastings.

\section{SUMMARY OF ARGUMENT}

Petitioner's brief demonstrates that there was no dual sovereignty doctrine before the mid-19th century. At the Founding and for several decades thereafter, a prosecution by one sovereign was understood to bar a subsequent prosecution by all other sovereigns. Dual sovereignty is thus contrary to the original meaning of the Double Jeopardy Clause. Defendants today enjoy a weaker form of double jeopardy protection than they did when the Bill of Rights was ratified.

\footnotetext{
${ }^{1}$ No counsel for a party authored this brief in whole or in part, and no person other than amici made a monetary contribution intended to fund the preparation or submission of this brief. Both parties have consented to the filing of this brief.
} 
But that fact only raises three further questions. First why did the Court erroneously conclude in Bartkus v. Illinois, 359 U.S. 121, 131 (1959), that the English and early American sources are "totally inconclusive" as to whether dual sovereignty existed at the Founding? Second, how, when, and why did the dual sovereignty doctrine come to exist? Third, given this history, why did the Court hold in United States v. Lanza, 260 U.S. 377 (1922), that a state prosecution does not bar a subsequent federal prosecution for the same conduct? This brief will answer these questions.

First, in Bartkus the Court simply misunderstood the English and early American sources.

Second, dual sovereignty grew out of the intense controversy over slavery in the period immediately before the Civil War. The Court invented dual sovereignty largely to prevent free states from blocking the recapture of fugitive slaves.

Third, by the time of Lanza, the dual sovereignty doctrine had been restated so often that the original meaning of the Double Jeopardy Clause had been forgotten. In Lanza, in any event, the Court was less concerned with original meaning than with rampant disregard for Prohibition. One purpose of dual sovereignty was to prevent "wet" localities from nullifying the Volstead Act.

In short, dual sovereignty is an accident of history. It was not part of the constitutional design. 


\begin{abstract}
ARGUMENT
Dual sovereignty is an accident of history; it was not part of the constitutional design.

\section{A. In Bartkus v. Illinois, the Court misun- derstood the English and early American sources relevant to the origin of dual sovereignty.}

The Court has examined the early sources relevant to the origin of dual sovereignty on only one occasion. In Bartkus v. Illinois, 359 U.S. 121 (1959), the Court devoted two paragraphs to the early sources, and concluded that the historical record is "totally inconclusive" as to whether dual sovereignty existed at the Founding. Id. at 131. This conclusion is mistaken. It rests on two major errors.

First, the Court refused even to consider the English cases, $R$. v. Roche, 168 Eng. Rep. 169 (Cr. Cas. 1775), and R. v. Hutchinson (1678) (which is described in Roche, 168 Eng. Rep. at 169 n.a, and in several other cases). The Court simply ignored Roche. As for the cases describing Hutchinson, the Court asserted that they are "dubious"-in part because they exist in different reported versions, and in part because "they reflect a power of discretion vested in English judges not relevant to the constitutional law of our federalism." Bartkus, 359 U.S. at 128 n.9.

Neither of these claims stands up to scrutiny. Roche exists in only one reported version. Hutchinson is indeed described slightly differently by different reporters, but every version says that a prosecution by one sovereign bars a subsequent prosecution by another. See Beak v. Thyrwhit, 87 
Eng. Rep. 124, 125 (K.B. 1688); Beak v. Tyrrell, 89 Eng. Rep. 411, 411 (K.B. 1688); Beake v. Tirrell, 90 Eng. Rep. 379, 380 (K.B. 1688); Burrows v. Jemino, 93 Eng. Rep. 815, 815 (K.B. 1727); Burroughs v. Jamineau, 25 Eng. Rep. 235, 236 (Ch. 1727).

And the cases do not reflect any discretion vested in English judges. They state a clear rule of law barring a subsequent prosecution. Had the Court been able to consider the English treatises along with the cases, the Court would have learned that the rule declared in the cases was repeated uniformly by commentators. See John Strange, A Collection of Select Cases Relating to Evidence 145 (1754); Henry Bathurst, The Theory of Evidence 39 (1761); 2 Timothy Cunningham, The Merchant's Lawyer 113 (1768); Francis Buller, An Introduction to the Law Relative to Trials at Nisi Prius 346 (1768); Leonard MacNally, The Rules of Evidence on Pleas of the Crown 428 (1802); 1 Thomas Starkie, A Treatise on Criminal Pleading 301 n.h (1814); 1 Joseph Chitty, A Practical Treatise on the Criminal Law 458 (1816). There was nothing dubious about it.

Second, the Bartkus Court misinterpreted Houston v. Moore, 18 U.S. 1 (1820). In Houston, the Court considered the possibility that a defendant might be tried twice for the same conduct, once by a state court and again by a federal court. The Court concluded that "if the jurisdiction of the two Courts be concurrent, the sentence of either Court, either of conviction or acquittal, might be pleaded in bar of the prosecution before the other." Id. at 31. In Bartkus, the Court erroneously concluded that Houston's reaffirmation of the traditional oneprosecution rule was meant to apply only in the unu- 
sual circumstance in which a state imposed criminal sanctions for a violation of a federal criminal law, not in the more common circumstance in which a state imposed sanctions for a violation of its own criminal law. Bartkus, 359 U.S. at 130 (referring to Houston, 18 U.S. at 28). In fact, Houston included no such limitation. The Pennsylvania statute at issue in Houston, which prohibited desertion from the militia, was worded similarly to the federal statute prohibiting desertion, Houston, 18 U.S. at 28, but, as the Houston Court correctly understood, Pennsylvania was enforcing one of its own criminal statutes, not the similarly-worded federal statute.

The Court's mistake in Bartkus is readily understandable. The purpose of Pennsylvania's desertion statute was to help the federal government punish deserters, at a time when the federal government was still quite weak. To achieve that end, the Pennsylvania statute was "in substance, a re-enactment of the acts of Congress, as to the description of the offence." Id. Houston accordingly explained that the purpose of the Pennsylvania statute was "to confer authority upon a State Court Martial to enforce the laws of the United States against delinquent militia men." Id. But by using the phrase "to enforce the laws of the United States," the Houston Court did not literally mean that Pennsylvania was enforcing a federal statute. Rather, the Court meant that Pennsylvania had added its enforcement efforts to those of the federal government, just as would be the case with similarly-worded state and federal statutes today.

Had the Barkus Court been able to consult early American treatises, it would have learned that Hou- 
ston was uniformly understood to mean that a prosecution by one sovereign would bar a subsequent prosecution by a second sovereign. James Kent's Commentaries on American Law, first published in 1826 , was the leading general treatise in the country. Kent discussed Houston at length. He explained that state and federal courts had concurrent jurisdiction in criminal cases, and that "the sentence of either court, whether of conviction or acquittal, might be pleaded in bar of the prosecution before the other." 1 James Kent, Commentaries on American Law 374 (1826). In this respect, Kent noted, criminal cases were just like civil cases, in that "the judgment of a state court, in a civil case of concurrent jurisdiction, might be pleaded in bar of an action for the same cause instituted in a circuit court of the United States." Id.

Specialized treatises declared the same rule. See William Rawle, A View of the Constitution of the United States of America 191 (1825); Thomas Sergeant, Constitutional Law 278 (2d ed. 1830); Edward D. Mansfield, The Political Grammar of the United States 137 (1835); Francis Wharton, A Treatise on the Criminal Law of the United States 137 (1846); Francis Wharton, A Treatise on the Law of Homicide in the United States 283 (1855).

The Bartkus Court thus erred in concluding that there was nothing to be learned from a review of the English and early American sources. The Court has not reviewed them since. 


\section{B. Dual sovereignty was invented by this Court shortly before the Civil War, large- ly as a way of preventing free states from blocking the recapture of fugitive slaves.}

This Court abandoned the traditional oneprosecution rule shortly before the Civil War, in three cases decided between 1847 and 1852: Fox $v$. Ohio, 46 U.S. 410 (1847), United States v. Marigold, 50 U.S. 560 (1850), and Moore v. Illinois, 55 U.S. 13 (1852). The primary reason appears to have been the concern that dual sovereignty would allow free states to thwart the recapture of fugitive slaves.

Fox was a state counterfeiting case in which the defendant argued that the federal government's power to punish counterfeiting was exclusive, not concurrent. In support of this argument, the defendant's lawyer posited the absurd consequences that he argued would flow from concurrent state and federal jurisdiction. "[I]f the power be concurrent," he pointed out, "[t]he weight of authority is decidedly in favor of the doctrine, that a conviction in either court is a bar to a prosecution in the other." Fox, 46 U.S. at 429. Whichever sovereign went first, the other sovereign would be prevented from prosecuting, which meant that a state could take power away from the federal government by getting to court faster. "Both the legislative and judicial powers of the United States are thus rendered abortive," he argued-the legislative power because Congress's statute could not be enforced, and the judicial power because the federal courts would be sidelined by the state prosecution. Id. at 430.

This argument highlighted a potential problem with the traditional rule, which was that it allowed a 
state to effectively nullify federal policy by racing to the courthouse and depriving the federal government of its power to prosecute. This would not be a problem in the area of counterfeiting, as there were no states with a policy of favoring counterfeiting or shielding counterfeiters from the federal government. In most areas of criminal law, the federal government likewise had little reason to worry that a state might attempt to subvert federal policy. But there was one very big exception-slavery.

There was already considerable controversy between the North and the South over slavery. Much of the controversy concerned the efforts of northern states to protect runaway slaves from being captured and returned to slavery. Timothy S. Huebner, Liberty \& Union: The Civil War Era and American Constitutionalism 59-61 (2016). The federal Fugitive Slave Act of 1793 made it a criminal offense to obstruct the capture of a fugitive slave, 1 Stat. 302, 305 (1793), but some northern states, including Pennsylvania, enacted statutes prohibiting the capture of fugitive slaves, in a deliberate effort to nullify the effect of the Fugitive Slave Act. In Prigg v. Pennsylvania, 41 U.S. 539 (1842), the Court put an end to this nullification strategy, by holding that the Fugitive Slave Act preempted Pennsylvania's statute. Abolitionists needed an alternative strategy.

The parade of horribles imagined by Fox's counsel, soon after Prigg, was almost certainly a thinly-veiled reference to slavery. If a state prosecution barred a subsequent federal prosecution, a state wishing to protect fugitive slaves had an obvious alternative to the kind of statute Prigg had rendered off-limits. Instead of prohibiting the capture of fugitive slaves, 
the state could prohibit the harboring of fugitive slaves. If the penalty was slight, or if the defendant could expect to be pardoned by the state governor, abolitionists harboring fugitive slaves would willingly surrender to state authorities. Once they were "prosecuted" in state court, they would be immunized from federal prosecution. The federal Fugitive Slave Act would be rendered toothless.

In Fox the Court thus expressed its first doubts about the traditional one-prosecution rule. "It is almost certain," the Court noted, "that, in the benignant spirit in which the institutions both of the State and federal systems are administered, an offender who should have suffered the penalties denounced by the one would not be subjected a second time to punishment by the other for acts essentially the same, unless indeed this might occur in instances of peculiar enormity, or where the public safety demanded extraordinary rigor." Fox, 46 U.S. at 435. The Court was suggesting that the one-prosecution rule was a matter of government grace rather than a strict rule of law, and that the rule could be suspended in extreme cases. The Court did not say what those extreme cases would look like, but it was most likely envisioning the circumstances that Fox's lawyer had imagined, cases in which a free state was intentionally subverting the Fugitive Slave Act. "But were a contrary course of policy and action either probable or usual," the Court concluded-i.e., were double prosecutions to become the norm-"this would by no means justify the conclusion, that offences falling within the competency of different authorities to restrain or punish them would not properly be subjected to the consequences which 
those authorities might ordain and affix to their perpetration." Id. That is, regardless of whether double prosecution was likely or unlikely, it was lawful.

Justice McLean defended the traditional oneprosecution rule in a lengthy dissent. "[T]o punish the same act by the two governments would violate, not only the common principles of humanity, but would be repugnant to the nature of both governments," he insisted. "There is no principle better established by the common law, none more fully recognized in the federal and State constitutions, than that an individual shall not be put in jeopardy twice for the same offence." Id. at 439 (McLean, J., dissenting).

The Court took its second step toward dual sovereignty two years later, in United States $v$. Marigold. Marigold was the inverse of Fox: the defendant had been convicted of counterfeiting in federal court, and he argued that state jurisdiction over counterfeiting was exclusive. The Court dispensed with this argument unanimously in a short opinion. Toward the end, the Court characterized Fox as having stated that "the same act might, as to its character and tendencies, and the consequences it involved, constitute an offence against both the State and Federal governments, and might draw to its commission the penalties denounced by either." Marigold, 50 U.S. at 569.

Moore $v$. Illinois, the third case, involved a state conviction for harboring a fugitive slave, and was thus exactly the kind of case that raised worries about allowing a state prosecution to bar a subsequent federal prosecution. The defendant was the prominent Illinois abolitionist Richard Eells. (Eells 
died while the case was pending; Moore was his executor.) Eells was the president of the Illinois AntiSlavery Party and the party's candidate for governor in 1846. He lived in Quincy, just a few blocks from the Mississippi River, across which lay the slave state of Missouri. His house was the first stop on the Underground Railroad for slaves escaping from Missouri. Eells was caught trying to hide a slave named Charley, who had swum across the river. He was convicted under state law of harboring a fugitive slave. ${ }^{2}$

The case attracted a great deal of attention, because of the intense controversy surrounding the question of how much power free states possessed to regulate the capture of fugitive slaves. Eells was represented by Salmon Chase, the future Chief Justice. Chase was then a Senator and one of the most well-known abolitionists in the country. He relied on Prigg to argue that federal jurisdiction with respect to fugitive slaves was exclusive, on the theory that if states lacked the power to impede the return of fugitive slaves to their owners, states should also lack the power to promote the return of fugitive slaves by prosecuting those who helped the slaves escape. Moore, 55 U.S. at 14-15.

As part of Chase's argument that only the federal government had the power to punish the harboring of fugitive slaves, he contended that federal jurisdiction had to be exclusive, or else a person might be unconstitutionally punished twice for the same offense. $I d$. at 19. But the issue of fugitive slaves pre-

2 National Park Service, Dr. Richard Eells House, https://www.nps.gov/nr/travel/underground/il3.htm. 
sented the worst possible context for invoking the traditional one-prosecution rule. The difficulty with the rule was that it could empower a state to nullify federal policy by beating the federal government to the courthouse, and slavery was the one area in which states clearly would make that attempt if they could. ${ }^{3}$

The Court thus had an especially pressing policy reason in Moore v. Illinois to reject Chase's invocation of the one-prosecution rule. The Court addressed the issue at length. "An offence, in its legal signification, means the transgression of a law," the Court began.

Every citizen of the United States is also a citizen of a State or territory. He may be said to owe allegiance to two sovereigns, and may be liable to punishment for an infraction of the laws of either. The same act may be an offence or transgression of the laws of both. Thus, an assault upon the marshal of the United States, and hindering him in the execution of legal process, is a high offence against the United States, for which the perpetrator is liable to punishment; and the same act may also be a gross breach of the peace of the State, a riot, assault, or a murder, and subject the same person to a punishment, under the State laws, for a misdemeanor or felony. That either or both may (if they see fit) punish such an offender, cannot be doubted. Yet it cannot be truly

3 The recently-enacted Fugitive Slave Act of 1850, like its 1793 predecessor, made it a federal crime to obstruct the recapture of a fugitive slave, 9 Stat. 462, 464 (1850), so it did not change anyone's incentive in this respect. 
averred that the offender has been twice punished for the same offence; but only that by one act he has committed two offences, for each of which he is justly punishable. He could not plead the punishment by one in bar to a conviction by the other.

Id. at 19-20. In this passage, the Court made clear that northern states could not nullify the Fugitive Slave Act by conducting sham prosecutions of their own. To do so, however, the Court had to elaborate a dual sovereignty doctrine that was exactly the opposite of the way the Double Jeopardy Clause had been understood since the Founding.

\section{In United States $v$. Lanza, the Court was concerned less with the original meaning of the Double Jeopardy Clause than with rampant disregard of Prohibition.}

In subsequent years, when the issue arose, the Court did not discuss or cite Houston or Furlong, its pair of 1820 cases stating that a prosecution by one sovereign would bar a subsequent prosecution by all others. See Houston, 18 U.S. at 31; United States $v$. Furlong, 18 U.S. 184, 197 (1820) ("there can be no doubt that the plea of autre fois acquit would be good in any civilized State, though resting on a prosecution instituted in the Courts of any other civilized State."). The Court merely cited its 1847-52 trilogy of Fox, Marigold, and Moore, and subsequent cases that rested on them. See Ex parte Siebold, 100 U.S. 371, 390 (1879) (citing Fox, Marigold, and Moore); Cross v. North Carolina, 132 U.S. 131, 139 (1889) (citing Fox, Marigold, and Moore); Pettibone v. United States, 148 U.S. 197, 209 (1893) (citing Cross); 
Crossley v. California, 168 U.S. 640, 641 (1898) (citing Cross); Southern Ry. Co. v. R.R. Comm'n, 236 U.S. 439, 445 (1915) (citing Cross); Gilbert v. Minnesota, 254 U.S. 325, 330 (1920) (citing Moore); McKelvey v. United States, 260 U.S. 353, 358-59 (1922) (citing Moore).

Between Moore in 1852 and Bartkus in 1959, the Court addressed the issue at length only once. The defendants in United States v. Lanza, 260 U.S. 377 (1922) were charged under the then-new Volstead Act, the federal Prohibition statute, with manufacturing and possessing liquor. They had already been convicted of the same offenses in Washington state court, as Washington had a prohibition law of its own. They moved to dismiss the federal indictment on the ground that it was barred by the Double Jeopardy Clause.

When the case reached this Court, the defendants received abysmal representation. Their counsel filed a meandering brief, the argument of which was quite hard to discern, a brief that did not seem to question the dual sovereignty doctrine. See Brief for the Defendants in Error, United States v. Lanza, 260 U.S. 377 (1922). Even Solicitor General James Beck was stumped. "If I correctly understand the argument of the counsel for the defendant," Beck politely began, "he does not question the power of the Federal Government . . . to punish cumulatively a citizen who by the same act has transgressed both the State laws prohibiting the manufacture or traffic in liquor and the national laws." Reply Brief for Plaintiff in Error at 1, United States v. Lanza, 260 U.S. 377 (1922). Beck understood Lanza's counsel to be arguing merely that the intent of Congress in the Volstead Act 
was that a liquor manufacturer should not be punished under federal law if he had already been punished under state law. Id. This was a very weak contention. "It is enough to say," Beck replied, "that no section of the Volstead law contains, either expressly or by implication, any such release of liability." Id. at 1-2. The Court understood Lanza's counsel to be making a different argument: that when states prohibited liquor they were acting under the authority of the Eighteenth Amendment rather than their own inherent police power, and that a state prosecution for manufacturing liquor was therefore tantamount to a federal prosecution. Lanza, 260 U.S. at 379-80. This too was a very weak contention, which the Court rejected unanimously. Id. at 380-82.

The United States was thus the only party in Lanza to make a coherent argument about dual sovereignty. Before even mentioning any of the cases, the government's brief emphasized that a oneprosecution rule would allow a state to nullify national Prohibition. "[I]t is quite obvious that State and Nation may widely and quite naturally differ" in their views of Prohibition, Beck noted. Brief for the United States at 4, United States v. Lanza, 260 U.S. 377 (1922). It was common knowledge that different parts of the country had radically different attitudes toward alcohol. In New York, for example, there was massive disregard of Prohibition right from the start. Michael A. Lerner, Dry Manhattan: Prohibition in New York City (2007). The potential for nullification was obvious, if a state prosecution barred a subsequent federal prosecution. "The State, taking into consideration the more drastic and far-reaching penalties of the Federal law, might content itself 
with imposing small or even nominal fines," the government's brief worried. Brief for the United States at 4. "As the sentiment for the enforcement of prohibition laws is believed to be inactive in some States, especially in some subdivisions thereof, it would follow that the State courts would virtually become in some localities 'cities of refuge' . . f from the effective action of the Federal Government." Id. at 5. If bootleggers flocked to New York and other "wet" cities, "[t]he nominal fines of a local magistrate, perhaps only a justice of the peace, might become the bootlegger's 'benefit of clergy." Id. at 5 . The government repeated this concern in its reply brief. "[A]s there is now a wide difference of opinion in various States with respect to the wisdom and justice of prohibition," the government cautioned, "it will follow that, in the States that are called 'wet,' the offender, by submitting to nominal punishments, will escape the rigor of the Federal laws." Reply Brief for Plaintiff in Error at 13.

The Court's opinion in Lanza duly noted all the cases establishing dual sovereignty, beginning with the trilogy of 1847-52, Fox, Marigold, and Moore. Lanza, 260 U.S. at 382-84. As usual, the Court did not mention any sources before 1847. Lanza's inept counsel had not cited them. (The United States cited Furlong, not Houston, and erroneously described Furlong as involving "questions of discretion, not of power." Brief for the United States at 18-19 (referring to Furlong by its informal name, U.S. v. Pirates).)

Toward the end of its opinion in Lanza, the Court acknowledged the concern about Prohibition enforcement that had been emphasized by the Solicitor 
General. "If a state were to punish the manufacture, transportation and sale of intoxicating liquor by small or nominal fines," the Court explained, "the race of offenders to the courts of that state to plead guilty and secure immunity from federal prosecution for such acts would not make for respect for the federal statute." Lanza, 260 U.S. at 385. Prohibition, like slavery, was an issue as to which states were certain to nullify federal policy if they were given half a chance. The purpose of dual sovereignty was to cut off that opportunity.

* * $*$

The lesson from this story is that dual sovereignty was not part of the constitutional design. It is an accident of history. It is a doctrine the Court created during the slavery crisis that led to the Civil War, and one the Court reinforced during Prohibition. In both instances, the Court was responding to the pressing political issues of the day rather than taking the longer view that constitutional interpretation often requires.

The Court's inattention to the early sources has become particularly unfortunate in recent years, as the Court has paid closer attention to the original meaning of the constitutional protections for criminal defendants. See, e.g., United States v. Jones, 132 S. Ct. 945, 949-50 (2012); Crawford v. Washington, 541 U.S. 36, $42-56$ (2004). Defendants today have weaker double jeopardy protection than they did at the Founding, when the Double Jeopardy Clause was understood to bar successive prosecutions by all sovereigns, not just the sovereign that prosecuted 
first. If judges can weaken constitutional protections for policy reasons that seem pressing at the time, one wonders what the Constitution is for.

\section{CONCLUSION}

The judgment of the Court of Appeals should be reversed.

Respectfully submitted,

PAUl G. CASSELL

STUART BANNER

S.J. Quinney College of Law University of Utah

Counsel of Record

338 S. University St.

UCLA School of Law

Salt Lake City, UT 84112 Supreme Court Clinic 405 Hilgard Ave. Los Angeles, CA 90095

(310) 206-8506

banner@law.ucla.edu 